\title{
Tworzenie relacji wychowawczych w pracy nauczyciela polonisty
}

\section{Creating educational relationships in the work of a Polish language teacher}

\author{
\# Aniwersytet Jagielloński w Krakowie
}

\begin{abstract}
The theme of the article is to create educational relationships in the work of a Polish language teacher. That relationship is the basis for creating ties between young and adults, and consists of several components. Firstly, boundaries and consequences as a framework for both sides. Secondly, time that the teacher should devote to students. Thirdly, the dialogue, which consists of formulating a friendly message, the ability to express emotions and attitudes focused on listening. The specificity of a educational relationship also builds classroom management style, which may be based on permissive attitude, restrictive or cooperating. The whole is crowned with the effectiveness of teacher performance based on specific skills and self-awareness.
\end{abstract}

Key words: educational relationships, classroom management styles, dialogue

Streszczenie: Tematem artykułu jest tworzenie relacji wychowawczych $\mathrm{w}$ pracy nauczyciela polonisty. Owa relacja jest podstawą więzi między młodymi a dorosłymi i składa się z kilku elementów. Po pierwsze granice i konsekwencje, jako ramy postępowania obu stron. Po drugie czas, który nauczyciel powinien poświecić uczniowi. Trzecim elementem jest dialog, na który składa się formułowanie przyjaznego komunikatu, umiejętność wyrażania emocji i postawa nastawiona na słuchanie. Specyfikę relacji wychowawczej buduje również styl kierowania klasą, który może być oparty na postawie przyzwalającej, restrykcyjnej lub współpracującej. Całość wieńczy skuteczność działalności nauczyciela, oparta na konkretnych umiejętnościach i świadomości własnych działań.

Słowa kluczowe: relacja wychowawcza, style kierowania klasą, dialog

Szkoła jest miejscem, w którym dużo czasu poświęca się na realizację zadań dydaktycznych, przygotowanie młodzieży do egzaminów czy sprawdzanie postępów uczniów w nauce. Większość nauczycieli mogłaby zadać pytanie: kiedy wychowywać? Poza tym w żadnym rankingu wyników szkoły nikt nie pyta o umiejętności interpersonalne uczniów, których przecież nie mierzą testy kompetencji ani nawet egzamin dojrzałości. Skąd zatem pomysł, aby pochylać się nad zagadnieniem, które w szkole jest traktowane marginalnie? 
Jasper Jull, duński terapeuta i pedagog, twierdzi:

pedagodzy i nauczyciele są równie odpowiedzialni za dzieci, jak rodzice, ponieważ spędzają z nimi tyle samo albo nawet więcej czasu. Kiedyś nauczyciele (...) zadawali sobie pytanie: czy mamy tylko uczyć, czy jeszcze wychowywać? W istocie każdy, kto przebywa z dziećmi, mimowolnie je wychowuje. Można spędzić z dzieckiem tylko pięć minut i przekazać mu pewien wzór zachowania, co może mieć skutek wychowawczy niezależnie od tego, czy padną przy tym jakieś słowa czy nie (Jull 2014, 18).

Szkoła jest zatem instytucją, w której obok zdobywania wiedzy merytorycznej, przedmiotowej, pokazującej jak działa świat, uczeń powinien nabyć pewnych kompetencji psychospołecznych, które pozwolą mu w tym świecie funkcjonować. Nie jest instytucją samą dla siebie. Maria Montessori ponad sto lat temu pisała, że „dziecko przygotowuje się do życia, a nie do szkoły” (Montessori 2005, 55). Instytucja edukacyjna powinna być postrzegana jako etap przejściowy, wprowadzający młodych ludzi do dorosłego życia. Na rynku pracy liczy się nie tylko wiedza, ale również samodzielność, umiejętność selekcji informacji, pomysłowość, kreatywność, komunikatywność i radzenie sobie ze stresem.

Zgodnie z raportem Szkoły Głównej Handlowej w Warszawie aż 32\% firm uznaje za główne kryterium wyboru pracownika kompetencje osobowe i interpersonalne. Na drugim miejscu ( $25 \%$ wskazań) lokuje się przygotowanie merytoryczne - akademickie i intelektualne. Poszukiwane są takie cechy oraz umiejętności, jak komunikatywność, dobra organizacja czasu, zaangażowanie i chęć ciągłego rozwoju (Budniowski i in. 2012). Z tego wynika, że obok umiejętności intelektualnych ważne są również kompetencje społeczne. Martin Herbert twierdzi, że rozwój społeczny oparty jest na paradoksie - ,jesteśmy istotami zarówno społecznymi, jak i indywidualnymi. Wchodzimy w najróżniejsze związki z innymi, w ostatecznym rozrachunku jednak zawsze samotnie stawiamy światu czoła" (Herbert 2005, 19). Ta dwoistość funkcjonowania w świecie każe nam z jednej strony - być członkiem zespołu, grupy, z drugiej - radzić sobie samodzielnie z powierzonymi zadaniami. W szkole można ćwiczyć i jedno, i drugie, jeżeli są ku temu stworzone warunki przez nauczyciela, tak zwana przestrzeń relacji wychowawczej, w której kształtowana jest osobowość partnerów współdziałania.

\section{Elementy relacji wychowawczej}

W tej przestrzeni spotykają się uczniowie i nauczyciele, ale do tych drugich należy określenie jej kształtu. Nauczyciel jest osobą odpowiedzialną za to, co dzieje się w klasie. To on powinien wyznaczać specyfikę wzajemnych relacji, budować charakter spotkania między nim a młodymi ludźmi. Jeżeli tego nie dokona, role się odwrócą i sytuację wzajemnego kontaktu zdefiniują uczniowie. Nauczyciel powinien pamiętać o swojej roli osoby dorosłej. Montessori twierdziła: 
jeśli nie ma dla nich autorytetu, dzieci nie mają wówczas żadnej orientacji. Wychowawczyni musi stać wyżej, nie może być koleżanką (...). Nauczycielka i dzieci w żadnym wypadku nie są sobie równi. Jest wystarczająco dużo dzieci w klasie, tak że wychowawczyni nie musi się stawać jeszcze jednym dzieckiem pośród nich (...). Dzieci potrzebują pełnego godności, dojrzałego człowieka (Montesori 1989, 27).

\section{Granice - reguły postępowania}

Osoba dorosła w klasie buduje klimat wzajemnych relacji przez określenie reguł postępowania, będących granicami wolności każdego uczestnika spotkania. Po co granice? Można wymienić kilka powodów: dają uczniom poczucie bezpieczeństwa, tworzą atmosferę zaufania i troski, pozwalają jasno określić wzajemne potrzeby, są pewną umową, według której wszyscy wiedzą, jak mają postępować, uczą młodych ludzi troski o innych. Granice są zatem ramami relacji wychowawczej. Czym są w praktyce? To reguły postępowania, zasady, zgodnie z którymi każdy uczestnik relacji kształtuje swoje zachowanie. One zawsze się pojawiają wcześniej czy później. Bez nich nie ma spotkania. Sposób ich wprowadzania jest uzależniony od zdecydowania i świadomości nauczyciela. Im mniej konkretnie dorosły będzie określał ramy relacji, tym bardziej będą to robić uczniowie. Przez swoje zachowanie młodzi ludzie będą testować, jak mogą kształtować swój zakres swobody. Jeżeli nauczyciel nie określi reguł postępowania na pierwszych lekcjach, to definiowanie sytuacji spotkania będzie trwało dłużej. Zwykle będzie się to działo przez prowokacyjne zachowania uczniów, które będą miały na celu sprawdzenie, kto i w jakim stopniu sprawuje kontrolę w klasie.

\section{Konsekwencje}

Drugim elementem relacji wychowawczej są konsekwencje, czyli skutki działań partnerów spotkania. W literaturze przedmiotu można znaleźć rozróżnienie między konsekwencjami naturalnymi i logicznymi. Te pierwsze „oznaczają wszystko, co jest rezultatem działania bądź braku działania dziecka, bez interwencji dorosłych" (Herbert 2005, 43). Przykładowo, jeżeli młody człowiek przemoczy buty, może nabawić się kataru. Jeżeli nie przeczyta zadanego przez nauczyciela tekstu, nie będzie wiedział, co było treścią lektury. W ten sposób na podstawie własnego doświadczenia dzieci uczą się bezpośrednich konsekwencji własnych decyzji. Poznają skutki swoich działań i uczą się dokonywać wyborów. Z kolei konsekwencja logiczna jest określona przez osobę dorosłą i ma związek z działaniem podopiecznego. Jeżeli uczniowie, grając w piłkę na placu szkolnym, zbiją szybę w oknie, to logiczną konsekwencją w zależności od postanowienia osób decyzyjnych może być zwrot kosztów wprawienia nowej szyby i/lub pomoc uczniów przy naprawie okna. W ten sposób młodzież uczy się ponoszenia odpowiedzialności za swoje czyny. Konsekwencja nie jest karą. Jest rezultatem, skutkiem pewnego działania lub działań. 
Konsekwencje są istotnym elementem ustalonych zasad. Jeżeli reguły są pewną umową, ustaleniem obowiązującym wszystkich uczestników relacji, to konsekwencje są skutkiem braku realizacji tej umowy. Są one wyrazem działania nauczyciela w przypadku konsekwencji logicznych. Jest to najtrudniejszy w praktyce element relacji, bo wymaga od nauczyciela konkretnych czynów. To jest wyraz realnie ustalonej granicy zachowania ucznia. Przykładowo, jeżeli zasadą jest podnoszenie ręki jako sygnału, że uczeń chce coś powiedzieć na lekcji, to konsekwencją będzie brak udzielenia głosu tym osobom, które nie stosują owej reguły. Warunkiem porządku na lekcji będzie zdecydowane działanie nauczyciela. Ile razy konsekwencja nie będzie wprowadzona w życie, tyle razy uczniowie dostaną sygnał, że ta reguła nie obowiązuje. Każdy wyjątek od reguły w stosunku do jednego dziecka jest sygnałem dla pozostałych, że granica jest ruchoma. Robert MacKenzie formułuje następujące postulaty:

Zasady w praktyce są definiowane poprzez Twoje działania lub przez to, czego Twoi uczniowie rzeczywiście doświadczają, gdy skończy się omawianie reguł. Postępowanie, które będziesz w stanie tolerować, wyznaczy standardy pracy w klasie. W jaki sposób uczniowie poznają Twoje zasady w praktyce? Będą je poddawać próbie, a następnie obserwować Twoje reakcje. Dzięki Twoim działaniom zrozumieją, czego naprawdę oczekujesz. (...) Lekcja zaczyna się w momencie, gdy Twoi uczniowie przekraczają próg klasy. Słuchają tego, co mówisz i obserwują to, co robisz. Im większa będzie zgodność pomiędzy Twoimi ustnymi zasadami a regułami stosowanymi w praktyce, tym szybciej uczniowie się do nich dostosują, potraktują je poważnie oraz odwzajemnią się współpracą i szacunkiem, na który zasługujesz. Konsekwencja jest kluczem do Twojej wiarygodności, jednak zabiera trochę czasu. Jak dużo? Jeżeli jesteś osobą bardzo konsekwentną, powinieneś umocnić swój autorytet w ciągu pierwszych 3-4 tygodni (MacKenzie 2008, 24-25)

\section{Czas}

Czas to kolejny istotny element relacji wychowawczej. Budowanie więzi między uczestnikami spotkania wymaga również inwestycji rozłożonej w czasie. Dotyczy to także nauki reguł obowiązujących w klasie. Nauczyciel powinien wykazać się cierpliwością w budowaniu struktury, czyli organizacji funkcjonowania klasy. Przez pierwsze tygodnie nauki w szkole uczniowie poznają obowiązujące zasady i uczą się ich na różnych lekcjach. Nie wszyscy nauczyciele wymagają tych samych ustaleń i nie wszyscy jasno je precyzują. Czasami zdarza się, że na różnych lekcjach obowiązują różne, często sprzeczne reguły. Uczniowie muszą mieć zatem czas, żeby przystosować się do odmiennej rzeczywistości funkcjonującej na różnych zajęciach.

Czas jest potrzebny nauczycielowi, aby poznał swoich uczniów, zrozumiał mechanizmy i przyczyny ich postępowania. W relacji nie można funkcjonować bez wzajemnego zrozumienia. Narzędziem poznania uczniów może być sporządzony przez każdego nauczyciela arkusz obserwacji, dostosowany do potrzeb i problemów występujących w klasie. Wzorem do wykorzystania może być poniższy przykład:

Polonistyka. Innowacje

Numer 2, 2015 
Tabela nr 1. Karta obserwacji zachowań ucznia

Imię i nazwisko

\begin{tabular}{|l|l|c|c|}
\hline Data & Rodzaj zachowania & $\begin{array}{c}\text { Okoliczności } \\
\text { zdarzenia }\end{array}$ & $\begin{array}{c}\text { Częstotliwość } \\
\text { występowania } \\
\text { zdarzenia }\end{array}$ \\
\hline & & & \\
& & & \\
\hline
\end{tabular}

\section{Dialog}

We wzajemnym spotkaniu uczniów i nauczycieli nieodzowne jest to, co związane jest z umiejętnością porozumiewania się przez kierowanie do siebie właściwie sformułowanych komunikatów i umiejętność ich odbioru, odczytania. Tu bardzo pomocne jest także nastawienie na słuchanie młodych ludzi. Jest to istotny aspekt wzajemnego zrozumienia, ale często pomijany w bezpośrednim kontakcie ucznia i nauczyciela. W szkołach nie buduje się kultury kontaktu poprzez rozmowę. Specyfiką komunikacji między nauczycielem a uczniem jest dominująca rola osoby dorosłej. To nauczyciel częściej i dłużej mówi na lekcji ${ }^{1}$, przez co krócej słucha ucznia. Komunikacja w szkole zazwyczaj odbywa się na lekcji i dotyczy realizacji zadań programowych. Dialog, który jest istotnym elementem relacji wychowawczej, odbywa się przeważnie między lekcjami, w czasie przerw lub wydarzeń typu wycieczki szkolne itp. Sytuacje trudne, konfliktowe też są ważnym momentem budowania więzi. W tego typu spotkaniach pojawiają się emocje, które często mogą być dla nauczycieli najtrudniejszą sferą kontaktu z uczniem. Dialog w relacji wychowawczej składa się z trzech istotnych części: komunikatu, emocji i nastawienia na słuchanie.

\section{Komunikat}

Psychologowie często podkreślają, że skuteczny komunikat to taki, który jest precyzyjny - odnosi się do zachowania i jest wyrażony w formie otwartej do dialogu. Analizując różne koncepcje poświęcone temu zagadnieniu, można wyróżnić pewne prawidłowości komunikacyjne. Po pierwsze, ważne jest nastawienie do rozmówcy. Ten aspekt podkreślony jest zwłaszcza w psychologii humanistycznej, w której dużą wagę przykłada się do symetrycznej relacji komunikacyjnej. Obie strony dialogu są tak samo ważne, tak samo zasługują na uwagę i szacunek. Ważne, aby się porozumieć. Po drugie, istotny jest sposób budowania wypowiedzi, który uzewnętrznia wzajemny stosunek rozmówców. Po trzecie, wypowiedzi towarzyszyć musi

\footnotetext{
1 Prawo Flandersa, tzw. Reguła 2/3 - tyle czasu na lekcji mówi nauczyciel do uczniów, a przez 1/3 lekcji uczniowie do nauczyciela, zob. Janowski, 1995, 103.
} 
zachowanie, które odzwierciedla wypowiadane słowa i okazywane emocje, które akceptowane są w kontakcie między osobami.

Śledząc budowę komunikatu, można w różnych koncepcjach wyodrębnić następujące części składowe:

Tabela nr 2. Analiza komunikatu według wybranych koncepcji humanistycznych

\begin{tabular}{|c|c|c|c|}
\hline \multirow[b]{2}{*}{$\begin{array}{l}\text { Elementy } \\
\text { komunikatu }\end{array}$} & \multicolumn{3}{|c|}{ Koncepcje psychologiczne ${ }^{2}$} \\
\hline & $\begin{array}{c}\text { Wychowanie } \\
\text { bez porażek } \\
\text { Thomasa } \\
\text { Gordona }\end{array}$ & $\begin{array}{l}\text { Porozumienie } \\
\text { bez przemocy } \\
\text { Marshalla } \\
\text { Rozenberga }\end{array}$ & $\begin{array}{l}\text { Analiza transakcyjna } \\
\text { Erica Berna }\end{array}$ \\
\hline $\begin{array}{c}\text { Nastawienie } \\
\text { rozmówców } \\
\text { do siebie }\end{array}$ & \multicolumn{3}{|c|}{$\begin{array}{l}\text { Empatia, wzajemny szacunek, wszyscy są tak samo ważni, } \\
\text { relacja bez uprzedzeń, nie ma lepszych i gorszych }\end{array}$} \\
\hline Język & $\begin{array}{l}\text { Uzależniony od } \\
\text { zdefiniowania po } \\
\text { czyjej stronie jest } \\
\text { problem }\end{array}$ & $\begin{array}{l}\text { Wskazany jest } \\
\text { język żyrafy }{ }^{3} \text {, } \\
\text { czyli prowadzący } \\
\text { do porozumienia }\end{array}$ & $\begin{array}{l}\text { Dostosowany do } \\
\text { aktualnego stanu ego } \\
\text { Rodzica, Dorosłego } \\
\text { lub Dziecka }\end{array}$ \\
\hline $\begin{array}{l}\text { Rodzaj } \\
\text { komunikatu }\end{array}$ & $\begin{array}{l}\text { Komunikat typu } \\
\text { „ja” lub aktywne } \\
\text { słuchanie }\end{array}$ & $\begin{array}{l}\text { Określanie spo- } \\
\text { strzeżeń, rozpo- } \\
\text { znawanie } \\
\text { i wyrażanie } \\
\text { uczuć, określanie } \\
\text { potrzeb, formuło- } \\
\text { wanie próśb }\end{array}$ & $\begin{array}{l}\text { Komunikat charakte- } \\
\text { rystyczny dla Rodzica } \\
\text { Krytycznego - oce- } \\
\text { ny, wartościowanie, } \\
\text { rozkazy, zakazy } \\
\text { Rodzica Opiekuńcze- } \\
\text { go - pochwały, troska, } \\
\text { wsparcie } \\
\text { Dziecka - wyraża emo- } \\
\text { cje } \\
\text { Dorosły - sformułowa- } \\
\text { nia rzeczowe, odno- } \\
\text { szące się do faktów, } \\
\text { uniezależnione od uczuć } \\
\text { i nastrojów, obiektywne } \\
\text { ocenianie i spostrzega- } \\
\text { nie }\end{array}$ \\
\hline
\end{tabular}

\footnotetext{
${ }^{2}$ Tabelę przygotowano z wykorzystaniem: Gordon 1955; Rosenberg 2008; Bern 1987.

${ }^{3}$ Zob. Rosenberg 2008.
} 


\title{
Emocje
}

Emocje są nieodłącznym elementem każdej wypowiedzi, same w sobie też niosą pewną informację, nadają komunikatowi określoną siłę i wyraz. Marshall Rosenberg twierdzi, że dzięki emocjom możemy rozpoznawać potrzeby swoje i innych, jesteśmy w stanie określać wewnętrzne granice dobrego samopoczucia i komfortu lub dyskomfortu tworzonej relacji. W początkowym okresie życia emocje służą jako swego rodzaju system alarmowy, a w kolejnych fazach rozwoju organizmu, pełnią funkcję motywacyjno-informacyjną, kierując uwagę na to, co jest istotne dla jednostki (Madalińska-Michalak, Góralska 2012, 86). Według Stevena Gordona emocjonalna sfera funkcjonowania człowieka ma wymiar kulturowy, a ludzie uczą się ją wyrażać na drodze socjalizacji, wchodząc we wzajemne interakcje (Madalińska-Michalak, Góralska 2012, 92-95). W rzeczywistości społecznej często uczucia są tematem tabu. Od wczesnego dzieciństwa ludzie uczą się, jak nie okazywać uczuć, zwłaszcza tych dyskomfortowych, jak gniew, złość, lęk itp. To powoduje, że często sfera emocjonalna jest poza kontrolą zarówno nauczycieli, jak i uczniów. Szkoła najczęściej nie jest przyjaznym miejscem, gdzie można uczyć się wyrażania przeżyć emocjonalnych występujących nie tylko podczas rozmowy, ale także w sytuacjach trudnych czy konfliktowych. Psychologowie - zarówno Gordon, jak i Rosenberg - mówią zgodnie: o emocjach trzeba mówić wprost. Trzeba nauczyć się je nazywać po to, aby móc je wyrazić. W ten sposób przejawia się spójność komunikacji werbalnej i pozawerbalnej. Elżbieta Sujak twierdzi: „proste nazywanie tego, co się rzeczywiście przeżywa, jest jedynym bezpośrednim sposobem wyrażania uczuć" (Sujak 2008, 70).

\section{Słuchanie}

Słuchanie związane jest z otwarciem się na drugiego człowieka, skierowaniem uwagi na rozmówcę. Według Sujak

\begin{abstract}
dla wartościowej rozmowy ważne jest tylko słuchanie prawdziwe. Polega ono na uważnym przyjmowaniu wypowiedzi skierowanej do mnie, staraniu się o jej zrozumienie, a także dostrzeganiu tego, co towarzyszy słowom, a więc stanowi przeżywanie rozmówcy. Prawdziwemu słuchaniu poświęca się całą uwagę, wyłączając własne komentarze, oceny i nasuwające się myślowe repliki i argumenty. Takie słuchanie może osiągać dużą intensywność odbioru treści, która wtedy bywa wiernie zapamiętywana (Sujak 2008, 26-27).
\end{abstract}

\section{Specyfika tworzenia relacji wychowawczej}

Tworzenie relacji wychowawczej w praktyce nauczyciela w dużej mierze zależy od stylu kierowania klasą. W literaturze przedmiotu wyróżnia się styl autorytarny, liberalny i demokratyczny. W rzeczywistości często te style przenikają się wzajemnie, nie występują w czystej postaci. 
Można jednak w zależności od występujących zachowań wskazać pewną dominację stylu. Od osoby dorosłej powinna zależeć ocena sytuacji i dobór właściwego zachowania.

Tabela nr 3. Specyfika relacji wychowawczej w zależności od stylu wychowania

\begin{tabular}{|c|c|c|}
\hline $\begin{array}{c}\text { Styl wychowania / } \\
\text { relacja wychowawcza }\end{array}$ & $\begin{array}{c}\text { Cechy } \\
\text { charakterystyczne }\end{array}$ & $\begin{array}{c}\text { Strategia rozwiązywania } \\
\text { problemów }\end{array}$ \\
\hline $\begin{array}{c}\text { Styl demokratyczny/ } \\
\text { relacja współdziałania }\end{array}$ & $\begin{array}{c}\text { Wolność wychowanka } \\
\text { wyznaczona określonymi } \\
\text { granicami }\end{array}$ & $\begin{array}{c}\text { Współdziałanie i branie } \\
\text { odpowiedzialności } \\
\text { za własne czyny }\end{array}$ \\
\hline $\begin{array}{c}\text { Styl liberalny / } \\
\text { relacja przyzwalająca }\end{array}$ & Wolność bez ograniczeń & $\begin{array}{c}\text { Perswazja } \\
\text { lub wycofywanie się }\end{array}$ \\
\hline $\begin{array}{c}\text { Styl autorytarny / } \\
\text { relacja restrykcyjna }\end{array}$ & Granice bez wolności & $\begin{array}{c}\text { Siła ze strony } \\
\text { wychowawcy }\end{array}$ \\
\hline
\end{tabular}

Styl autorytarny jest charakterystyczny dla tradycyjnej szkoły Jana Fryderyka Herbarta (Kupisiewicz, 1996). Jego charakterystyczną cechą jest przewidywalność. To, co charakteryzuje ten styl budowania relacji, to surowa dyscyplina. Dzieci „współpracują” pod naporem nagród i kar. Ten system wychowania często powoduje uległość bądź bunt u wychowanka. Obowiązuje zasada: dzieci bezwzględnie maja słuchać dorosłych, którzy narzucają ustalone przez siebie normy i zasady. W swoim zachowaniu dorośli kierują się przekonaniem, że zawsze mają rację i nie należy $\mathrm{z}$ nimi dyskutować.

Podejście przyzwalające to wychowanie bezstresowe. Pojawiło się ono jako reakcja na wychowanie autorytarne. Wraz z nowym nurtem pedagogicznym zwanym Nowym Wychowaniem, wielu nauczycieli i rodziców szukało bardziej liberalnej strategii oddziaływania na młodzież, opartej na wolności, równości i szacunku. Te postulaty niełatwo było wprowadzić osobom, które wychowane były w podejściu restrykcyjnym. W stylu przyzwalającym wolność bez granic często stawała się anarchią, a dzieci wychowywane i kształcone w akceptacji na wszystko nie uczyły się szacunku dla zasad i autorytetu. Nie potrafiły odpowiedzialnie kształtować swojej wolności. Obecnie styl liberalny wyraża się postawą rodziców, gdzie dzieci dostają to, na co mają ochotę $\mathrm{w}$ danej chwili. Liczy się przede wszystkim dobro dziecka. W szkole panuje chaos, uczniowie przeszkadzają na lekcji, nie współpracują z nauczycielem. Brak jest jasno określonych reguł obowiązujących w klasie. Nauczyciel nie stawia granic, zostawia swobodę w działaniu uczniom, a w sytuacji konfliktowej wycofuje się.

Styl demokratyczny jest niczym złoty środek. Godzi podejście restrykcyjne, narzucające wolę dorosłych z całkowitym wycofaniem się 
i oddaniem pola dzieciom. W tym typie relacji możliwa jest równowaga pomiędzy stanowczością a szacunkiem. Obrazowo można to wyrazić następująco:

Styl autorytarny / relacja restrykcyjna stanowczość pozbawiona szacunku

\author{
Styl demokratyczny / \\ relacja współdziałania - \\ równowaga między \\ szacunkiem a stanowczością
}

\author{
Styl liberalny / relacja \\ przyzwalająca - wyraża \\ szacunek pozbawiony \\ stanowczości
}

Pierwsze dwa podejścia (autorytarny i liberalny) pokazują relację w opozycji, konfrontacji. W tych ujęciach zawsze ktoś jest wygrany lub przegrany. Uczeń i nauczyciel są po dwóch stronach barykady. Trzecie podejście demokratyczne kształtuje relacje na zasadzie współpracy. Nie ma rywalizacji i konfrontacji. W tym ujęciu nauczyciel wyznacza ramy i w tym obszarze jest stanowczy, ale w obrębie określonych granic pozwala na inicjatywę uczniom. Pojawia się pole do dyskusji, wzajemnego dialogu. W ten sposób eliminowane jest niepożądane zachowanie dzieci, które uczą się właściwych działań w atmosferze akceptacji i szacunku. Wszystko odbywa się przy założeniu, że musi panować równowaga między stanowczością i szacunkiem. Gwarancją sukcesu jest działanie osoby dorosłej, która podejmuje odpowiedzialność za klasę, wyznacza granice zachowania uczniów (ani za szerokie, ani zbyt wąskie) i pozwala uczniom w obrębie wyznaczonych ram podejmować własne decyzje, za które ponoszą oni odpowiedzialność. Wolność postępowania, możliwość decyzji jest w tym ujęciu wartością, którą uczeń dostaje na miarę swoich umiejętności wykorzystania jej. W tym ujęciu relacja jest współdziałaniem opartym na mądrości i odpowiedzialności osoby dorosłej, do której należy ostateczna decyzja. Współdziałanie nie jest tutaj współpartnerstwem. Nauczyciel i uczeń nie są w pozycji równorzędnej. Osoba dorosła jest zawsze krok do przodu. Dzieci mają możliwość wyboru, współdecydowania, ale w obszarze wyznaczonym przez wychowawców. Nauczyciel jest jak koryto rzeki, które wyznacza przepływ wody, ale nie ogranicza jej. Silne brzegi pozwalają utrzymać się rzece w jej naturalnym biegu, nie rozlewa się ona na boki. Tak samo wychowawca potrafi wyznaczyć podopiecznemu granice, w których może on najlepiej się rozwijać. Jak powinno wyglądać to $\mathrm{w}$ praktyce?

\section{Budowanie relacji wychowawczej}

W tym działaniu można sformułować cztery kroki postępowania:

1. Sformułowanie razem $\mathrm{z}$ uczniami ważnych dla wszystkich zasady postępowania;

2. Ustalenie konsekwencji, określenie, co będzie się działo, kiedy zasady zostaną złamane;

3. Reagowanie w sytuacji testowania przez uczniów granic, czyli stosowanie konsekwencji;

4. Wzmacnianie pozytywnych zachowań. 


\section{Jak formułować zasady?}

Przede wszystkim ustalanie zasad powinno odbywać się razem z uczniami. Dobrze jest pozwolić im na wyrażenie swojego zdania, które zasady są dla nich ważne i dlaczego. Pytania: po co ustalamy reguły postępowania oraz czemu one służ pozwalają uczniom na refleksję na temat istnienia pewnych umów społecznych, bez których trudno byłoby funkcjonować. Wszystko to służy większemu zrozumieniu wprowadzania zasad i ich akceptacji. Zasady powinny być sformułowane językiem zrozumiałym dla uczniów, aby były czytelne dla tych, którzy mają ich przestrzegać. Nie powinny być ani zbyt szerokie, ani zbyt wąskie - ważne, żeby omówić z młodzieżą, do jakich zachowań odnoszą się nasze ustalenia. Należy czuwać, aby w miarę możliwości zasady odnosiły się do reakcji pożądanych i nie były zakazami, czyli nie zaczynały się od „NIE”.

\section{Jak ustalać i wdrażać konsekwencje?}

Zamiast kar stosować konsekwencje naturalne (jako skutki określonych działań) lub logiczne (wypływające z określonych zachowań), odpowiednie do wieku dziecka, możliwe do realizacji, adekwatne do przewinienia. Słowa należy popierać czynami. Bez negocjacji, bez straszenia i obiecywania, że dane zachowanie się pojawi. Wprowadzenie konsekwencji może być poprzedzone informacją, że złamanie danej reguły wiąże się z określonym skutkiem, ale kolejnym krokiem jest czyn. Tu liczy się stanowczość i nieuchronność następstwa zdarzenia. Ten moment postępowania jest ważny, ale i trudny zarazem. Istotne jest, aby nie uczynić z tego momentu walki i konfrontacji z uczniem, ale też nie ulec namowom, prośbom czy uporowi dzieci. Tu przydaje się umiejętność komunikacji, w której słowa są spójne z czynami.

\section{Jak wzmacniać pozytywne zachowania?}

Wskazanie niepożądanych zachowań nie wystarczy. Nauczyciel może pomóc wychowankom w kształtowaniu odpowiednich postaw, wskazując dobre wzorce, czyli wzmacniając właściwe działania dzieci. Odbywać się to może przez pochwały i akcentowanie konkretnych zachowań. Ważne jest, aby chwalić odpowiedni czyn, a nie dziecko. W ten sposób nie naznacza się osoby etykietą i nie kształtuje się jej poczucia wartości na podstawie dobrego lub złego zachowania. Żeby pochwała była skuteczna, powinna być udzielana najszybciej jak to możliwe, tak aby wzmocnienie pozytywne było wiązane z konkretnym czynem. Aprobata powinna precyzyjnie określać, czego dotyczy, jakiego konkretnego działania. Sformułowania ogólnikowe typu: dobrze, super, ładnie - to często nic nieznaczące określenia, które nie pełnią funkcji rzeczywistego wzmocnienia. Dobra pochwała nie musi zawierać sądów wartościujących, lepiej żeby dokładnie opisywała właściwe zachowanie. Przykładowo, nauczyciel zamiast powiedzieć do ucznia:

Polonistyka. Innowacje

Numer 2, 2015 
„ładnie napisałeś to wypracowanie”, z większym skutkiem może sformułować bardziej szczegółową wypowiedź typu: „W ostatnim wypracowaniu popracowałeś nad stylistyką wypowiedzi. Popełniłeś tylko jeden błąd, który z pewnością umiesz poprawić. Nie zrobiłeś też żadnego błędu ortograficznego". Konkretna pochwała ma funkcję edukacyjną, kształtującą, korygującą i rzeczywiście wzmacniającą. W pozytywnym wzmocnieniu zachowania ważna jest też spójność wypowiedzi. Dlatego dobrze jest, aby komunikacja werbalna i pozawerbalna były jednolite. Słowa powinny być uzupełniane przez gesty, mimikę twarzy, np. uśmiech, ton głosu.

Skuteczność pochwał widać wtedy, kiedy dotyczą one również małych rzeczy, starań uczniów, a nie tylko spektakularnych wyników. Dobre rezultaty przynosi dowartościowanie starań dzieci w obecności osób dla nich ważnych, np. rodziców. W ten sposób podnosi się rangę zachowania, a rodzice mogą być sprzymierzeńcami nauczycieli, zwłaszcza w odniesieniu do dzieci, które sprawiają duże trudności. Dobrze, kiedy praca nad właściwym postępowaniem jest też okazją do samozadowolenia i własnej satysfakcji. W ten sposób młodzi ludzie uczą się, że wartość ma również to, co oni sami czują.

Podczas pracy z uczniami nad ich właściwym zachowaniem nauczyciel może stosować kilka technik działania. Po pierwsze, może kształtować otoczenie klasy - modyfikować je np. przez zmianę umeblowania sali, zmianę ustawienia ławek, dodanie pomocy dydaktycznych lub zlikwidowanie nadmiaru elementów. Po drugie, wychowawca powinien poszukiwać różnych sposobów i metod pracy z uczniami w zależności od trudności, jakie się pojawiają. Po trzecie, uczniowie mogą być bardziej angażowani w pracę dydaktyczną, np. przez jej wspólne zaplanowanie, ustalenie, co i kiedy będzie się działo $\mathrm{w}$ tygodniowym lub miesięcznym okresie. Wreszcie istotny jest też sposób komunikacji, budowanie wypowiedzi wprost, bez ironii, złośliwości itp.

\section{Relacja wychowawcza w pracy nauczyciela polonisty}

Praca nauczyciela polonisty w wymiarze tworzenia relacji wychowawczej jest szczególna na pewno w dwóch wymiarach. Po pierwsze, ze względu na specyfikę przedmiotu nauczania, po drugie, na szczególną rolę, jaką pełni polonista w wychowaniu dzieci i młodzieży. Te dwie płaszczyzny splatają się i pozwalają nauczycielowi uczynić swoiste narzędzie oddziaływania wychowawczego z lekcji języka polskiego. To w wymiarze tego przedmiotu nauczyciel w sposób naturalny może stać się mistrzem, który mówi o ważnych rzeczach i ilustruje je własnym przykładem. Szczególnie jest to możliwe podczas analizy utworów literackich, w których pojawiają się określone wartości, postawy czy przekonania. Refleksja nad sprawami zasadniczymi z jednej strony może kształtować osobowość młodych ludzi, a z drugiej budować więź między wychowawcą a uczniami. Zatem praca 
polonisty nie sprowadza się tylko do kształtowania podstawowych umiejętności językowych, jest czymś więcej i obejmuje głębsze rejony. Dlatego tak ważne jest to, kim jest nauczyciel języka polskiego i czego chce nauczyć młodych ludzi. Pisze o tym Anna Sitarz-Janus, wskazując szeroki wachlarz możliwości oddziaływań dydaktyczno-wychowawczych polonisty:

nauczyciel w swoich działaniach nieustannie porusza się w różnych regionach wartościowania w sposób bezpośredni (np. rozważając z młodymi ludźmi kwestie hierarchii wartości; ucząc ich charakterystyki postaci czy krytycznego opisu zjawisk kultury; kształcąc ich umiejętności werbalizowania swoich ocen itd.) i pośredni: czy to przez wspólne odkrywanie wartości estetycznych w dziele literackim, czy to przez przekazywanie uczniom wiedzy na temat zmian w wartościowaniu danego tekstu kultury (jak odczytywali i oceniali ten tekst jego współcześni, a jak - kolejne generacje) oraz przez podejmowanie decyzji o charakterze metodologicznym (dotyczących np. wyboru lektury, metody jej analizy, pytań problemowych kierujących dyskusję etc.). Te ostatnie działania winny być szczególnie poddawane stałej samokontroli, aby subiektywizm aksjologiczny uczącego nie naruszał odpowiedzialności za takie kształcenie ucznia, które przygotuje go do samodzielnego wyboru wartości (Janus-Sitarz 2008, 13-14)

Zatem praca polonisty to całe spektrum możliwości oddziaływań, ale również wielka odpowiedzialność, troska i delikatność w budowaniu kontaktu z młodymi ludźmi. To również otwartość na świat i drugiego człowieka. Według Janus-Sitarz

polonista, aby spełnić rolę wychowawcy, musi być ogromnie wyczulony na wszelkie zmiany, jakie zachodzą w szeroko rozumianej kulturze, zarówno tej wysokiej, niezastygłej przecież w starych ramach ocen i sposobów interpretacji, jak i tej masowej, mającej obecnie największy wpływ na młodych ludzi, na kształtowanie ich gustów, potrzeb, ambicji. Musi też mieć świadomość, że właściwie każda jego aktywność w interakcji z literaturą i uczniem jest nacechowana aksjologicznie (Janus-Sitarz 2008, 13)

A jak widzą to sami zainteresowani, którzy przygotowują się do zawodu nauczyciela polonisty? Studenci kończący pierwszy rok polonistycznych studiów licencjackich Uniwersytetu Jagiellońskiego ${ }^{4}$ traktują relację wychowawczą jako więź, interakcję między uczniem a nauczycielem bądź wzajemny stosunek wychowanka i wychowawcy. W tych określeniach mieści się wzajemna otwartość, zaufanie, tworzenie autorytetu nauczyciela, jego zaangażowania w kontakt z uczniem, czy wychodzenie poza schematy. Studenci podkreślają konieczność łączenia zadań wychowawczych z dydaktycznymi i zgodni są co do tego, że polonista nie jest tylko nauczycielem, ale jest także wychowawcą, wzorem do naśladowania, mistrzem. Ilustracją mogą być następujące wypowiedzi:

Otóż, według mnie relacja wychowawcza sa to stosunki między nauczycielem a uczniem. Jest to budowanie więzi, między pedagogiem a jego uczniem. Dzięki tej relacji, możliwe jest realizowanie programu nauczania a jednocześnie kształtowanie postawy ucznia. Umożliwia to przekazywanie wiedzy oraz zasad. Porozumienie

4 Wypowiedzi studentów uzyskane są na podstawie wywiadu na temat relacji wychowawczej. Badania przeprowadzone w czerwcu $2015 \mathrm{r}$.

Polonistyka. Innowacje

Numer 2, 2015 
między tymi stronami pozwala na utrzymywanie porzadku oraz dyscypliny. $W$ polskiej szkole, nauczyciel powinien bardziej „pochylać się” nad uczniem, dostrzegać indywidualne różnice $w$ grupie dzieci, rozmawiać, rozumieć, wychodzić naprzeciw zainteresowaniom dziecka i pozwalać na ich rozwój.

Relację wychowawcza rozumiem jako WIĘŹ między uczniem a nauczycielem. Jest to możliwe, kiedy nauczyciel porzuci formę pt. Wchodzę do klasy, robię albo nie robię, co do mnie należy i wychodzę. Moim zdaniem owa więź można zacieśnić, kiedy nauczyciel aktywnie SŁUCHA tego, co uczeń ma do powiedzenia. Traktuje go podmiotowo, a nie przedmiotowo, używa metod aktywizujacych, organizuje wycieczki klasowe, wyjazdy integracyjne i rzetelnie przeprowadza godziny wychowawcze (nie tylko uzupełnia dziennik).

Moim zdaniem relacja wychowawcza to wzajemny stosunek wychowanka i wychowawcy. Jest on bardzo ważny, bo znaczaco wpływa na to, czym dziecko się zainteresuje i jak będzie podchodziło do danego przedmiotu. Zazwyczaj małe dzieci emocje dotyczace nauczyciela przenosza na prowadzony przez niego przedmiot. $W$ ten sposób łatwo moga się zniechęcić lub zainteresować czymś. Starsi uczniowie potrafia rozdzielić stosunek do nauczyciela od przedmiotu, ale nie zawsze chca. Czasem wola za coś obwiniać wychowawce niż sami coś zrobić. Relacja ta jest bardzo ważna, ponieważ jest jakimś wzorem dla młodego człowieka, który dopiero poznaje świat i na podstawie tego co zobaczy i czego doświadczy, będzie budował stosunki z innymi.

Myślę, że wychowawca powinien pamiętać o tym, że $w$ tym okresie, $w$ którym dzieci chodza do szkoły, następuje ich prężny rozwój (psychiczny, intelektualny). W tym czasie dzieci czy młodzież poszukuja wzorców osobowych, chociaż nieczęsto się do tego przyznaja. Przestaja im wystarczać rodzice. Szukaja wśród obcych, często wśród nauczycieli. Dlatego wśród nich, bo to ich widzq na co dzień, a nie sq oni nieosiagalnymi idolami z telewizji. Poza tym praca wychowawcy wiąze się z pewna. dyscyplina, taka osoba powinna umieć wymagać od siebie. Musi codziennie wstać i pójść do pracy, poprowadzić zajęcia, wypełnić dokumenty, kontrolować zachowanie uczniów, pilnować by nic im się nie stało. To ten zawód a nie inny dzieci znaja z codzienności. Widza jakich metod używaja nauczyciele, aby osiagnaćć spokój na lekcji czy posłuszeństwo. Takich metod i oni zaczynaja używać, jeśli uznaja je za skuteczne i spodobaja im się. Wychowawca (nauczyciel) musi także pamiętać, $\dot{z}$ jego podopieczni sa od niego młodsi, ale potrafia myśleć i analizować. Potrafia oceniać jego prace (czy jest rzetelna i potrzebna $w$ tej formie, $w$ jakiej ja prezentuje uczacy) i jego zachowanie. Widza, czy jest uczciwy względem nich i samego siebie. Widza, czy przychodzi przygotowany, czy wie, o czym mówi. Potrafia też być wyrozumiali, gdy dowiedza się o jakichś poważnych problemach prowadzacego.

Wydaje mi się, że relacja wychowawcza to interakcja między uczniem a nauczycielem lub między dzieckiem a rodzicami, pokazanie różnych możliwości rozwiązania problemu, przekazanie wzorców zachowań, otwieranie umysłu dziecka na otaczajacy świat i nauczenie go samodzielnego myślenia. (...) Nauczyciel powinien być wzorem dla ucznia, być miły i sympatyczny, ale również surowy i przestrzegajacy określonych zasad; ma być otwarty na uczniów i ich pomysły, pomagać im się realizować, okazać wsparcie w trudnych chwilach i przede wszystkim ma budzić zaufanie. Wydaje mi się, że takie coś można osiagnać przez wspólne wyjazdy/wycieczki, organizowanie zajęć lekcyjnych czy zwykłe prowadzenie lekcji w ciekawy i barwny sposób. 
W powyższych wypowiedziach można zauważyć troskę i zaangażowanie. Widać, że osoby przygotowujące się do zawodu nauczyciela wykazują świadomość i zrozumienie dla potrzeby budowania relacji wychowawczej jako istotnego elementu kontaktu między nauczycielem a uczniem.

\section{Relacja wychowawcza - postulaty dla nauczycieli}

Stwierdzenie, że w szkole nie ma czasu na budowanie relacji wychowawczej, jest mitem, który ugruntował się w świadomości wielu osób. Żeby obalić ten sposób myślenia, można dokonać paru przewartościowań:

1. przesunąć środek ciężkości z realizacji materiału na obserwację potrzeb uczniów i dostosowanie pracy na lekcji do ich możliwości;

2. dialog uczynić podstawową formą kontaktu z uczniami;

3. budować świadomość swojej pozycji jako nauczyciela i wychowawcy odpowiedzialnego za to, co dzieje się w klasie;

4. zmienić w sobie sposób myślenia $\mathrm{z}$ „nic nie mogę zrobić”, na „mogę zrobić to, co zaplanuję i to, o czym marzę”;

5. uwierzyć, że praca może być pasją i okazją do rozwoju dla każdego nauczyciela.

\section{Bibliografia:}

Berne Eric, 1987, W co graja ludzie? Psychologia stosunków międzyludzkich, Warszawa.

Budniowski Adam., Dąbrowski Dorota, Gąsior Urszula, Macioł Stanisław, 2012, Pracodawcy o poszukiwanych kompetencjach i kwalifikacjach absolwentów uczelni - wyniki badań, www.e-mentor.edu.pl/artykul/index/numer/46.id/946 (dostęp: 13.10.2015).

Gordon Thomas, 1995, Wychowanie bez porażek w szkole, Warszawa.

Herbert Martin, 2005, Co wolno dziecku? Rozsqdne ustalanie granic, Gdańsk.

Janowski Andrzej, 1995, Uczeń w teatrze życia szkolnego, Warszawa.

Janus-Sitarz Anna, 2008, Uwierzyć w potęge wartości, w: Janus-Sitarz A. (red.), Wartościowanie a edukacja polonistyczna, Kraków.

Jull Jasper, 2014, Kryzys szkoły. Co możemy zrobić dla uczniów, nauczycieli i rodziców, Podkowa Leśna.

Kupisiewicz Czesław, 1996, Podstawy dydaktyki ogólnej, Warszawa.

MacKenzie Robert, 2008, Kiedy pozwolić, kiedy zabronić w klasie, Gdańsk.

Madalińska-Michalak Joanna, Góralska Renata, 2012, Kompetencje emocjonalne nauczyciela, Warszawa.

Montessori Maria, 2005, Domy dziecięce, Warszawa.

Montessori Maria, 1989, The Child, Society and the World, Oxford.

Rosenberg Marshall, 2008, Porozumienie bez przemocy. O języku serca, Warszawa.

Sujak Elżbieta, 2008, Psychologia komunikacji, Kraków. 


\section{O Autorce:}

Agnieszka Guzik, doktor nauk humanistycznych w zakresie pedagogiki, magister socjologii, adiunkt w Katedrze Polonistycznej Edukacji Nauczycielskiej na Wydziale Polonistyki Uniwersytetu Jagiellońskiego. Swoje zainteresowania naukowe koncentruje wokół szkoły jako przestrzeni współdziałania nauczycieli (szczególnie polonistów) i uczniów oraz metody Marii Montessori we współczesnej edukacji. 
